музичній культурі України другої половини ХХ ст. Харків, ХДАК, 2001.210 с.

5. Немкович О. Українське музикознавство ХХ ст. як система наукових дисциплін. Київ, 2006. 534 с.

6. Ростовський О. Теорія і методика музичної освіти. Тернопіль: Богдан, 2011. 640 с.

7. Черкасов В. Музично-просвітниціка діяльність Б.Асаф'єва, В.Шацької, Б.Яворського. Випуск 121 (II). 2013. C. 126

8. Шульгіна В. Українська музична педагогіка. Київ: ДАКККіМ, 2005.271 c.

\section{REFERENCES}

1. Antonyuk, V. Boleslav Leopoldovych Yavorskyy: hrani osobystosti [Boleslav Leopoldovich Yavorsky: the facets of personality]. Scientific Bulletin. National Music Academy of Ukraine named after P.I. Tchaikovsky. No. 113. pp.109-127. [in Ukrainian].

2. Afanasyev, Y. \& Jura, O. (2009). Profesiyna pidhotovka muzykanta: uroky Boleslava Yavorskoho [Professional training of a musician: lessons of Boleslaw Jaworski]. Kyiv, 128 p. [in Ukrainian].
3. Kuzmina, L. (1984). Pro vykonavsku estetyku B. Yavorskoho [On the performing aesthetics of B. Yavorsky]. No. 19, Kyiv, pp.37-51. [in Ukrainian].

4. Martinyuk, A. (2001). Dyryhentsko-khorova osvita $v$ muzychniy kulturi Ukrayiny druhoyi polovyny XX st. [Conducting and choral education in the musical culture of Ukraine in the second half of the twentieth century]. Kharkiv, 210 p. [in Ukrainian].

5. Nemkovich, O. (2006). Ukrayinske muzykoznavstvo $X X$ st. yak systema naukovykh dystsyplin [Ukrainian musicology of the twentieth century as a system of scientific disciplines]. Kyiv, 534 p. [in Ukrainian].

6. Rostovsky, O. (2011). Teoriya i metodyka muzychnoyi osvity [Theory and methods of music education]. Ternopil, $640 \mathrm{p}$. [in Ukrainian].

7. Cherkasov, V. (2013). Muzychno-prosvitnytsika diyalnist B.Asafyeva, V.Shatskoyi, B.Yavorskoho [Musical and educational activity of B. Asafyev, V. Shatskaya, B. Yavorsky]. No. 121 (II), p.126. [in Ukrainian]. 8. Shulgina, V. (2005). Ukrayinska muzychna pedahohika [Ukrainian music pedagogy]. Kyiv, 271p. [in Ukrainian].

Стаття надійшла до редакції 22.08.2020

УДК 781.6

DOI:

Марія Ярко, кандидат мистецтвознавства, доцент, доцент кафедри музикознавства та фортепіано Дрогобииького держаного педагогічного університету імені Івана Франка

Марія Каралюс, магістр педагогічної освіти, старший викладач кафедри музикознавства та фортепіано

Дрогобииького держаного педагогічного університету імені Івана Франка

\title{
АНАЛІЗ МУЗИЧНИХ ТВОРІВ У ВЕРСІї ГЕРМЕНЕВТИКИ МУЗИЧНОГО ТЕКСТУ
}

На сьогодні предметний регламент навчальної дисчипліни “Аналіз музичних творів” набув модальності авторської музикознавчої творчості. Тому пропонована стаття має змістом міркування на тему діагностики музичних творів у версії основ герменевтики музичного тексту; відтак - звільнення від формально-логічної спечіалізації знань щзодо “форми-схеми” музичного твору. Суть такої постановки питання вбачається у порушенні проблеми алгоритмів аналітичного проробляння реального музичного тексту як “тексту” культури та методики розпізнавання изього тексту у дискурсі герменевтичного (тлумачного) практикуму.

Ключові слова: алгоритми тлумачного аналізу музичних творів; архітектоніка світу музики.

Jim. 6.

Mariya Yarko, Ph.D.(Art History), Associate Professor of the Musicology and Piano Department, Ivan Franko State Pedagogical University Mariya Karalyus, Master of Education, Senior Lecturer of the Musicology and Piano Department Ivan Franko State Pedagogical University

\section{ANALYSIS OF MUSICALWORKS INTHE VERSION OFMUSICALTEXT'SHERMENEUTICS}

The rules of the subject like "Analysis of musical works" have now outgrown its status and gained the modality of the author's musicological work. Therefore, the proposed article devoted to the blessed memory of the outstanding Ukrainian musicologist N. A. Horyukhina, the founder of modern Ukrainian systematic musicology, has the content of the reasoning on the implementation of analytical algorithms for the diagnosis of musical works in the version of the foundations of the hermeneutics of musical text. According to the authors of the article, setting such a problem was long overdue, since the algorithms of the formal-logical specialization of knowledge about the "form" of a musical work were not just outlived, but also became a considerable didactic threat in terms of insolvency to reach the essence of the author's intention and his ideas at the level of intonation processing of the musical matter 
of a particular musical work. After all, finding out the essence of the "individual" is unthinkable outside the Absolute (musical universals) - its unique replication itself, which should be thought of considering the architectonics of the world of music as a definite systemic education, which is organized not only by the stylistic (sound-physical), but also the methodological levels. That is, the newest type of methodological reflection, which is generally aimed at a holistic understanding of the world of music, is both didactically and heuristically fruitful in the intention to comprehend the essence of musical expression and its hermeneutic reception in the inherent semantic meanings of a real musical text. Therefore, the prospects for further research in this direction are seen in tolerance to the intellectually inspired understanding of certain patterns in organizing the world of music precisely as a soundintonation environment and art of intonated meaning - from the adaptation of certain sound forms / ideas to their comprehension as the sound-intonation Continuum of the "World of Music". The essence of the problem statement in its general form and in connection with the scientific and practical tasks important for the present is seen in the issue of algorithms for analyzing the real musical text as a "text" of culture and methods for recognizing this text in the discourse of the hermeneutic (interpretative) practical work.

Keywords: algorithms for the interpretive analysis of musical works; architectonics of the world of music.

П остановка проблеми. У числі прихильників ідей Б. Асаф'єва щодо процесуального здійснення музичної матерії, що ще у 20-х рр. ХХ ст. буквально збурили тогочасне теоретичне музикознавство і опісля довготривалого “забуття”, чи радше ігнорування та ідеологічної заборони були відроджені у часі так званої “перебудови” (др. пол. 80-х рр. ХХ ст.), осібним чином вирізняється постать Н. Горюхіної як фундатора сучасного українського систематичного музикознавства: оминаючи ідеологічні перепони, дослідниця достеменно обгрунтовує наукову значущість категорії інтонації для становлення новітнього теоретичного музикознавства, яке було опертим на принципи семантичної конкретизації абстрактних понять [3, 10]. А отже, присвячуючи цю статтю світлій пам'яті Н. Горюхіної (з нагоди сторіччя від ії дня народження), сміємо стверджувати, що іiі унікальної сили інтелектуальний дар й надалі спричиняється до кардинальних змін у лоні української музикознавчої думки на поч. XXI ст. Як відомо, передовсім Н. Горюхіна ініціювала постановку питання саме щодо драматургічної перспективи композиційної форми в “експресивному модусі структури", що буквально нівелювало собою постановку питання щодо догматів “форми-схеми”. У цьому, власне, і полягала фундаментальність музикознавчої ініціативи дослідниці, яка фактично боролася із банальним визначенням поняття "будови" музичного твору на користь його "структури"; тобто - у дефініціях суто внутрішнього узгодження композиційно-драматургічних функцій певної структуротворчої ідеї. Відтак уважаємо, що алгоритми формально-логічної спеціалізації знань щодо так званої “форми” музичного твору не просто віджили, але й становлять чималу дидактичну загрозу в плані неспроможності дійти суті авторського задуму та його ідеї на рівні інтонаційного процесування музичної матерії завжди конкретного музичного твору. Адже 3'ясування суті “одиничного” є буквально немислимим поза межами Абсолюту (музичних універсалій) - його унікального відтворення, про яке мусимо говорити з огляду на архітектоніку світу музики як певного системного утворення, що $є$ організованим не лише за стилістичними (звукофізичними), але також металогічними рівнями.

Аналіз основних досліджень і публікацій. Передусім відзначимо, що услід за аналітичною практикою Н. Горюхіної буквальний прорив у методиці аналізу музичних творів здійснила аналітична розробка В. Москаленка щодо діагностики "інтонаційної моделі" як "певної одиниці музично-інтонаційного коду" [4, 51]. Цією установкою дослідник доволі чітко означив "місце" конструювання музичного мислення, яке завжди має або загальноісторичне, або індивідуально-стильове обумовлення; тому первинний аналітичний контакт із реальним музичним текстом мусить мати уповні чіткі аналітичні алгоритми щодо визначення самої моделі музичного мислення на зразок світовідчуттєвого звороту думки під виглядом “порухів душі” (визначення В. Бобровського [1, 32]). Але діагностика безпосередньо інтонаційної моделі, яка, на думку В. Москаленка, й повинна підлягати “проінтонуванню”, повинна принаймні бути дидактично забезпечуваною алгоритмами щодо ії аналітичного розпізнавання.

Мета статті - у прогностичному моделюванні такого аналітичного дискурсу, коли виокремленню підлягає не що інше, як сегмент - така частка цілого, що несе у собі інформацію про це ціле. Тобто, робиться спроба завжди мати на увазі певне загальне та особливе, які й визначають унікальність одиничного - музичний артефакт. Задля цього пропонується інваріантна модель архітектоніки світу музики як певної універсалії, що містить у собі рівневі позначення, зосередження уваги на яких має здатність узгодити поміж собою інтенції музикознавчого 
аналізу завжди конкретного музичного тексту як “тексту” культури.

Виклад основного матеріалу. Для кожного фахового музикознавця вирішальну роль має причетність до певної теоретичної школи, включаючи при цьому витоки формування його музикознавчої свідомості. Однак правдиве усамостійнення музикознавця відбувається синкретично - в моделі синтезування та переосмислення постулатів, що в подальшому визначає його власну “картину” розуміння сенсу музикознавчого знання. Для більшості сучасних музикознавців такий шлях привів до усталення практики особистісного дискурсу та авторської ініціативи, але далеко не для усіх визначальним виявився намір осмислення світу музики як архітектонічної цілості у його питомих іманентних характеристиках. Причиною тому $є$ історично набута звичка диференціювати фактичний ресурс реального музичного тексту в манері формальнологічної спеціалізації знань про світ музики; а саме - констатації та опису його стилістичних фігур поза бодай приблизним декодуванням їхніх семантичних значень. Усе це й спричиняє фатальність наслідків ігнорування новітніх аналітичних методик опрацювання реального музичного тексту як “тексту” культури, про які було заявлено ще у 80-х рp. ХХ ст. у вигляді алгоритмів семіотичного та герменевтичного методів аналізу як таких, що передбачають семантичну інтерпретацію власне тексту та його достовірну (з огляду на алгоритми структурування морфології змісту і вистежування генетики сутнього) герменевтичну рецепцію засобом дискурсивної практики.

Саме тому пропонована читачам стаття присвячується проблемі осмислення аналізу музичних творів у версії основ герменевтики музичного тексту, у випадку чого у належний на те понятійний спосіб буде віднайдена можливість для “декодування" стилістичних значень реального музичного тесту як “знакових” свідчень задуму музичного творіння та одиничного вираження архітектоніки Світу музики. Науковий сенс такого завдання полягає у дотриманні умов так званої тоталогічної (від лат. totus - увесь, цілий) методології, яка, сповідуючи принцип духовного освоєння світу, визначає світоглядні пріоритети синергетичної наукової картини світу та похідну від неї ідею “філософії цілісності”. Відповідно, практична значущість розгляду проблем навчальної дисципліни “Аналіз музичних творів” та музикознавчої практики з аналізу музичного твору у версії основ герменевтики музичного тексту вбачається у докорінній зміні їхньої методологічної основи - зреченні від алгоритму констатації та опису формальнологічних даних (синтаксична одиниця, масштабні пропорції, тип форми-схеми тощо) на користь сповідування ідей Б. Асаф'єва щодо музики як мистецтва інтонованого смислу.

Зокрема, увазі читача пропонується особливий алгоритм осягнення архітектоніки світу музики, який (услід за аксіомами Б. Асаф'єва) є звукоінтонаційним середовищем: ця характеристика іманентної суті музичного мистецтва як Світу музики виводиться авторами статті у ранг інтонаційного Континууму і позначається знаком “вічності” - горизонтально перегорнутого числа “вісім”. Цей простір пропонуємо уявити собі у вигляді об'ємного кола, усередині якого поступово будуть з'являтися певні позначення - у ролі мислеформ зі зворотною від числа "вісім" нумерацією (доцентровий вектор поширення): спершу це будуть металогічні рівні архітектоніки світу музики - від числа 7 до 5 у графічній версії послідовного масштабного звуження кіл; опісля - його стилістичні значення від числа 4 до 1 у графічній версії послідовного масштабного звуження квадратних площин.

А отже, в осередді інваріантної моделі архітектоніки світу музики (позиція 1) постає поняття “інтонаційної моделі” - конструктивного наміру на інтонаційний спосіб відтворення певного смислу засобом музичної лексики та стилістичної комбінаторики. Тобто, на первинному рівні аналітичної практики мається на увазі діагностика типів музичної лексики або ж “типів інтонування”, судження стосовно яких формуються на основі спостережень за поведінковим характером елементів музичного мовлення. Бо, власне, сукупність лексем музичного тематизму й дає підставу для герменевтичної рецепції музичного вислову на рівні “інтонаційного моделювання”.

Услід за тим (позиція 2) аналітичний дискурс спрямовується на осягнення “інтонаційного рельєфу тематичного матеріалу” в сенсі осягнення типів емоційно-психологічних реагувань як перших підстав для діагностики музичної образності. Власне на цьому рівні осягається процесуальний характер здійснення первинної інтонаційної моделі, ії модифікацій та переходу до суттєво відмінних лексичних конструкцій (тут докорінно інший тип інтонаційної моделі).

Наступний рівень осягнення процесуального здійснення музичного тематизму (позиція 3) - це рівень композиційно-драматургічної логіки втілення музичного задуму, коли з'ясовується тип структуротворчої ідеї та її драматургічне амплуа (рід композиційної форми). 
Фактично завершальним у сенсі суто стилістичного значення володіє наступний рівень (позиція 4) - рівень осмислення семантичного амплуа жанрової форми як певного типу змісту. Однак жанрова спеціалізація музичного задуму - це останній момент осмислення не стільки суто стилістичних ресурсів музичного твору, скільки семантичного інваріанту жанрової форми. Наприклад, кантата - це модальність оспівування та звеличування певного ідеалу; ораторія тлумачення істинного; симфонія - суголосся світоглядних ідей щодо концепції життєдіяльності історичного типу людини; елегія - смуток за втраченим тощо.

Мусимо, проте, ще раз вказати на специфіку графічного вираження суто стилістичного ресурсу музичного тексту: якщо уявити собі архітектоніку світу музики у вигляді об'ємного кола, то його осереддя й будуть становити конструктивно (у вигляді квадратів) та головне - відцентровим вектором позначені вищезгадані рівні:

- від інтонаційної моделі (позиція 1);

- крізь інтонаційний рельєф тематичного матеріалу (позиція 2);

- його композиційно-драматургічний дискурс (позиція 3);

- та типізований жанровою формою зміст (позиція 4).

Відповідно, услід за графічними позначеннями у вигляді квадратів йдуть уже кола, які несуть у собі сенс металогічних позначень:

- позиція 5 - естетичної програми стилю;

- позиція 6 - історично актуальної “духовної ситуації часу";

- позиція 7 - історично актуальної світоглядної парадигми із пріоритетною світосприймальною настановою як “саме такого буття у саме так зрозумілому світі” (визначення В. Петрушенка [5, 221]).

А отже, вийшовши за межі стилістичних значень музичного тексту у виміри його металогічних значень фактично усі його значення змикаються на позначенні Абсолюту (позиція 8) - інтонаційного континууму світу музичних ідей, який попри варіантність стильових проєкцій (наприклад, у версії “стильових словників епох”) завжди передбачає архітектонічно урівноважене співвідношення іманентних рівнів музичного мислення.

Так, щодо музичної лексики як стилістичного ресурсу інтонаційної моделі варто докласти зусилля, аби поведінковий характер елементів музичного мовлення щодо певної музичної лексеми як звукової форми/ідеї був розкритий у їй властивому смисловому значенні (кантиленний тип інтонування - як “спів душі”; декламаційний
- у виразовій сукупності мовленнєвої характерності музичного вислову в плані увиразнення розмовної артикуляції; моторика -у руховій модальності метро-ритмічної характерності ритмо-формули; загальні форми руху - в модальності загального настроєвого відтінку фігурацій чи пасажного прийому; сигнальність у модальній характерності заклику до емоційновольової зібраності; звукова імітація - в алюзіях до асоціативних значень образності).

Своєю чергою, діагностика інтонаційного рельєфу музичного тематизму мусить бути зосереджена на його процесуальному здійсненні - за типами "порухів душі" (визначення В. Бобровського [1, 32]), які, зокрема, завжди мають у собі відтворення світовідчуттєвої модальності в плані або раціоналістичної, або ірраціональної постави, що свідчать про тип історично актуальної світосприймальної настанови - предметової, ентузіастичної, рефлексивної, споглядальної саморефлексії тощо.

Услід за тим рівнево необхідною $є$ діагностика типу структуротворчої ідеї, яка розпізнається на основі певного композиційного принципу (сонатність, рондальність, варіаційність, варіантність тощо) та його драматургічного амплуа згідно із типами драматургічних співвідношень сегментів концепції: діалектичний - конфліктно-драматичний (сонатність, класичний сонатно-симфонічний цикл); параболічний - i3 різкими зміщеннями-зсувами у значеннях образності (бароковий тип контрастно-складової як типу суцільно-складової циклічної форми); лінійний або “сюжетний” (сюїтний тип циклічної організації); тотожність (найбільшою мірою цей тип драматургічного співвідношення стосується куплетної строфіки).

Відтак узагальнює власне стилістичний профіль музичного тематизму вже жанровий рівень, який стосується принципів типізації змісту у його семантичній інваріантній структурі.

Однак услід за тим настає момент щоразу то більших одкровень, які немов повертають свідомість до усіх попередніх рівнів аналітичного практикуму, оскільки їхня істинна суть покликана набувати текстуально виправданих значень у розрізі: естетичної програми історично актуального стилю (позиція 5); “духовної ситуації часу” культурно-історичного моменту або індивідуально-особового світовідчуттєвого спектру композитора (позиція 6); історично актуальної моделі світорозуміння та світовідношення (аксіологічної, теологічної, антропоцентричної з домінантністю або ratio або eтотіо тощо) (позиція 7). 
Тобто, фактично у регламенті описаної інваріантної моделі архітектоніки світу музики є необхідність у почергових реверсних співвідношеннях поміж суто стилістичними значеннями реального музичного тексту (нагадаємо, що їх графічне вираження в архітектоніці світу музики виокремлено засобом концентрично розташованих фігур квадратів) та його металогічними значеннями (їх графічне вираження в архітектоніці світу музики виокремлено засобом концентрично виражених кіл) - від актів ідентифікації реальних стилістичних значень до їхньої аргументації у суто метафізичних значеннях як свідчень завжди історично актуального обумовлення якостей самого музичного тексту.

Наприклад, музика XX ст. - це передусім особливий спосіб звукомислення, що заступив собою здобуту класичною (академічною) традицією системність мово-мислення і виявив особливу ауру щодо ментальної природи “образу” власне стилю: класичну модель “автономного типу стилю” (В. Медушевський) заступили смислові інтенції концепції так званого "змішаного стилю" з алюзійним (заснованим на алюзіях як виду непрямого цитування чи натяку) способом його розвитку за умов “полюсу стильового притягання”, який актуалізував архетипи музичної історії під виглядом ремінісценцій та їхньої реінтерпретації як акту неореставрації культури. Зокрема, стилетворчий механізм алюзій відкрив пріоритетну для усього ХХ ст. “ідею глобального культурного синтезу” (вислів О. Козаренка), що спричинила появу новітнього методу стилеутворення в моделі “інтерпретуючого” типу стилю. Відповідно, “образ” музики ХХ ст. є опертим не лише на “інновацію”, але також на “рецепцію” культурної пам'яті, про що вельми промовисто свідчить загальновідома теза: “ХX сторіччя - сторіччя інтерпретацій”. Отже, відсутність розуміння ментального складу такого (інтегрованого) “образу” унеможливлює його адекватну й евристично плідну виконавську рецепцію та слухове сприймання" $[6,40]$.

Відтак спеціалізована педагогічна характеристика мислення як уміння створювати виправдані судження та оперувати інформацією потребує принаймні такої методологічної стратегії, коли йдеться про виокремлення специфічного продукту аналізу - під виглядом найпростішої одиниці психічного, яка має усі основні властивості цілого і є його неподільною “живою” частиною.

А отже, йдеться про певний перелік уповні конкретних аналітичних передумов так званого каузально-динамічного аналізу; адже якщо зазвичай аналіз як такий передбачає “розкладання" цілого на складові частини й тим самим обмежує можливість вивчення цілого в усій його складності й багатоманітності, бо зводиться до процесів більш елементарного порядку, то натомість для здійснення каузально-динамічного аналізу необхідно дотримуватися цілком конкретних умов.

Умова перша - аналізувати “процес", а не “річ”. Стосовно музичного вислову та вираження це значить, що є необхідним, наприклад:

- не констатувати розмір метричного такту, а розглядати інтонаційний тип метричної стопи (ямб, хорей, дактиль, амфібрахій, анапест, розряд пеону);

- не вичислювати конструкцію форми-схеми, а тлумачити композиційно-драматургічну логіку - вид структуротворчої ідеї та іiї драматургічне амплуа;

- не вказувати на “риси” стилю, а з'ясовувати його металогіку та ментальність як психічного оснащення.

Умова друга - виявляти реальні каузальнодинамічні зв'язки, а не зовнішні (фенотипні) ознаки процесу. Стосовно аналізу музичного твору це значить, наприклад:

- не стільки фіксувати наявність музичної теми, скільки виявляти стилістичний ресурс інтонеми та інтонаційної моделі як первинної звукової форми музичної матерії, на основі якої слід здійснювати спостереження за процесуальним характером здійсненням інтонаційного рельєфу тематичного матеріалу твору;

- визначати музичний жанр не за виконавським ресурсом, а в означеннях структурносемантичного інваріанту жанрової форми згідно iз типом жанрового змісту та його семантичним забезпеченням.

Умова третя - здійснювати генетичний аналіз, який відтворює особливості процесів розвитку: в архітектоніці музичного тексту - це заданість стилістичної системи історично-актуальною світоглядною парадигмою, “духовною ситуацією часу” (вислів Карла Ясперса) в культурі та модальності індивідуального досвіду світовідчуття, провідними художніми ідеями мистецької епохи та естетичною програмою стилю.

Однак інтеграційні рухи поміж конструктами архітектоніки світу музики належить артикулювати вже в алгоритмах ідеї когнітивної експансії музичної свідомості (від лат. cogito міркую; expansio - розширення, вихід із початкових меж), що зросла в дусі епістемологічних (знаннєвих) перетворень у лоні 
сучасної музикознавчої думки і покликана розв'язувати завдання щодо прояснення структури (а не “будови”) музичного Тексту його устрою, внутрішньої організації, системного взаємозв'язку складових тощо. Безпосередньо реалізація цієї ідеї пов'язана передусім з такою особливістю самого образу-моделі, що в його умовах свідомість реципієнта довільно рухається у відцентровому та доцентровому напрямах семантично “прочитуючи” архітектоніку музичного тексту як “текст” культури. І в усьому цьому вбачається потужний особистіснорефлексивний когнітивний (а отже, творчий) потенціал реципієнта, який здатний методом експансії музичної свідомості випереджувати розуміння кожного із рівнів інтонаційного поля музики на умовах його заданості. Відтак кожен із вимірів стилістичного забезпечення музичного тесту (інтонаційна модель, інтонаційний рельєф тематичного матеріалу, композиційнодраматургічний план, жанрова форма) мають можливість бути сприйнятими як задані у своєму унікальному (одиничному) вираженні у зв'язку 3 метавимірами (естетична програма стильової системи, духовна ситуація часу або ж специфіка історичного моменту культури, історично актуальна світоглядна парадигма) - тобто, як “мегатекст" культури. Більше того, описаний спосіб діяльності музичної свідомості покликаний забезпечувати пізнання щоразу інших музичних світів у різних стильових моделях, коли реципієнт не буде мати залежності від певного стильового зразка як норми чи правила тощо. Бо передусім важливою $є$ “картина свідомості”, що іії визначає специфіка дій інтелекту: у ньому все відбувається “під дією рефлексії” i “в сфері рефлексії”, а тому “розвинена свідомість розуміє знання як змістовні утворення в межах безперервної рефлексії” (В. Петрушенко [5, 43]).

Висновки 3 даного дослідження i перспективи подальших розвідок у даному напрямку. Викладені судження щодо такої процедури, як аналіз музичного твору, мали основою переконання щодо доцільності спирання на основи герменевтики (тлумачення) реального музичного тексту як завжди унікального, а тому одиничного, вираження Абсолютної ідеї інтонаційного Континууму Світу музики. Доведено, що новітній тип методологічної рефлексії, яка загально спрямована на цілісне (холістичне) розуміння світу музики, $\epsilon$ i дидактично, і евристично плідною в намірі осягнення суті музичного вираження та його герменевтичної рецепції у властивих семантичних значеннях реального музичного тексту. Тому перспективи подальших розвідок у вказаному напрямі вбачаються у толеранції до інтелектуально наснаженого розуміння певних закономірностей щодо організації світу музики саме як звукоінтонаційного середовища та мистецтва інтонованого смислу - від адаптування певних звукових форм/ідей до їхнього осягнення як звукоінтонаційного Континууму Світу музики.

\section{ЛІТЕРАТУРА}

1. Бобровский В. П. Тематизм как фактор музыкального мышления: очерки. В 2-х вып. Москва: Музыка, 1989. Вып. 1. 268 с.

2. Горюхина Н. А. Постановка проблемы творческого метода в теоретическом музыкознании. Очерки по вопросам музыкального стиля и формы : сб. трудов. Київ: Музична Україна, 1986. C. $16-25$.

3. Горюхіна Н. А. Наукові основи теоретичного музикознавства. Питання методологї радянського теоретичного музикознавства : зб. статей /упор. Н. О. Горюхіна. Київ: Музична Україна, 1982. С. 5-17.

4. Москаленко В. Г. До визначення поняття “музичне мислення". Украӥнське музикознавство: зб. статей. Київ: НМАУ, 1998. Вип. 28. С. 4853.

5. Петрушенко В. Л. Епістемологія як філософська теорія знання : монографія. Львів : Видавництво Державного університету “Львівська політехніка", 2000. 296 с.

6. Ярко М. І., Кавецька В. В. Звукові ідеї новітнього музичного мистецтва: на матеріалі концертної програми “Авангардна (і не тільки) фортепіанна музика XX ст." у виконанні О. Стрілецької та О. Позднишевої. Молодь $i$ ринок. № 3 (68), 2017. С. 35-43.

\section{REFERENCES}

1. Bobrovskyi, V. P. (1989). Tematizm kak faktor muzyikaalnogo myishleniya: ocherki. V 2 vyp. [Thematism as a factor of musical thinking: essays. In 2 vol.] (Eds). G. Golovinskiy, Yu. Paisov, E. I. Chigaryova, N. Shahnazarova. Moscov, Vol. 1, 268 p. [in Russian].

2. Goryuhina, N. A. (1986). Postanovka problemyi tvorcheskogo metoda $v$ teoreticheskom muzyikoznanii [Statement of the problem of the creative method in theoretical musicology]. Essays on musical style and form: a collection of works. Kyiv, pp. 16-25. [in Russian].

3. Horiuhina, N. A. (1982). Naukovi osnovy teoretychnoho muzykoznavstva [Scientific basis of theoretical musicology]. Questions of the 
methodology of Soviet theoretical musicology: a collection of articles. Kyiv, pp. 5-17. [in Ukrainian].

4. Moskalenko, V. G. (1998). Do vyznachennia poniattia "muzychne myslennia" [To the definition of "musical thinking"]. Ukrainian musicology. (Eds.) I. Liashenko. Kyiv, Vol. 28, pp. 48-53. [in Ukrainian].

5. Petrushenko, V. L. (2000). Epistemologiia yak filosofska teoriia znannia : monohrafiia [Epistemology as a philosophical theory of knowledge: monograph].
Lviv : State University “Lviv Polytechnic”, 296 p. [in Ukrainian].

6. Yarko, M. I. \& Kavetska, V. V. (2017). Zvukovi ideyi novitnioho muzychnoho mystetstva [The ideas of sound in modern musical art: based on the concert program "Avant-garde (and not only) piano music of the $20^{\text {th }}$ century" performed by O. Striletska and O. Pozdnysheva]. Youth \& market. Issue 3 (68), 2017. pp. 35-43.[in Ukrainian].

УДК 378.37.01:78

DOI:

Чень Лян, аспірант факультету мистецтв імені Анатолія Авдієвського Національного педагогічного університету імені М.П. Драгоманова, м. Київ

\section{ХУДОЖНЬО-ЦІННІСНА СФЕРА УЧИТЕЛІВ МУЗИКИ В КОНТЕКСТІ ФАХОВОЇ ПІДГОТОВКИ}

Аналізується сутність художніх иінностей учителів музики: стосовно учителя як особистості $i$ стосовно його готовності до формування иінностей учнів. Показано відмінність традиційно музичних цінностей учителя музики і художніх иінностей як інтегрального феномена, щзо акумулює цінності з різних видів мистецтва; розглянуто його структуру. Проаналізовано потенціал дисциплін фахової підготовки (музично-теоретичних, музично-виконавських, музично-методичних) для формування художньо-иіннісної сфери студентів-музикантів.

Ключові слова: особистісні художні цінності; учитель музики; музична діяльність; поліхудожність.

Jim. 13.

Chen Lyan, Postgraduate Student of Faculty of Arts named after Anatoliy Avdiyevskiy, Mykhaylo Drahomanov National Pedagogical University, Kyiv

\section{ARTISTIC AND VALUE SPHERE OF MUSIC TEACHERS IN THE CONTEXT OF PROFESSIONAL TRAINING}

The essence of artistic values of music teachers is analysed: in relation to them as personalities and in relation to their readiness to formation the students' values. The author relies on the thesis that the professional activity of music teacher is a priori the artistic and aesthetic activity like the creative process of an artist with his or her inherent drama. The difference between traditional music values of music teacher and artistic values as an integral phenomenon that is dynamic, holistic, personally and professionally significant, permanently developed in the process of artistic cognition of works of different arts and characterized by semantic modernity for the subject; aims at self-improvement in the field of art around musical values, determines the effective and practical attitude to their spread in society. The semantic-component structure of the phenomenon (motivational-emotional, cognitivereflexive, practical-activity, artistic-communicative semantic components) is considered. The relevance of the factor "value polyartistic" in professional training of student-musician with a focus on the formation of musical values is emphasized. The specifics of different types of art from the standpoint of their mastery of personality are studied. The content of types of musical activity of student-musician is analysed: acquisition of knowledge about music, performance, analytical activities, verbal interpretation, research, lecture, pedagogical practices, based on the perception of music and projected into the plane of transmission of musical and aesthetic experience to future students. The value potential of disciplines of professional training (music-theoretical, music-performance, musicmethodological) for formation of artistic and value sphere of students is revealed. The core role of experience and artistic communication in the process of forming the teacher's personal values is proved.

Keywords: personal artistic values; a music teacher; musical activity; music-theoretical disciplines; musicperformance training; music-methodological training; polyartistic.

П

остановка проблеми. Визнані цінності мистецтва різних епох і національних культур акумулюють духовний досвід людства. Проте суперечливий інформаційний простір, в якому співіснують художні цінності й антицінності, загострюе проблему ціннісного формування особистості в соціокультурних реаліях. Учитель музики є носієм 